\title{
Plant of the Millennium, Caper (Capparis spinosa L.), chemical composition and medicinal uses
}

Mohamad Hesam Shahrajabian ${ }^{1 *+} \mathbb{0}$, Wenli Sun ${ }^{1+}$ and Qi Cheng ${ }^{1,2,3}$

\begin{abstract}
Background: Caper (Capparis spinosa L.) is a common member of the genus Capparis, which is a perennial shrub and thorny, and a common aromatic plant in many parts of the world, especially the Mediterranean regions.

Main body: The aim of this mini-review was to outline the most significant health benefits of caper in both traditional and modern pharmaceutical medicine. Scientific databases such as PubMed, Science Direct, Scopus, Research Gate, and Google Scholar with emphasis on Science Direct and Scopus have been used. A review of literature was carried out using the keywords caper, Capparis spinosa, health benefits, pharmaceutical benefits, natural products, and caper bush. During the writing of the review, the time period in which the papers were published had not been selected since the focus was on significant researched selected for the areas covered in this mini-review. The main components of its aerial parts are cappariloside A, stachydrin, hypoxanthine, uracil, capparine A, capparine $\mathrm{B}$, flazin, guanosine, $1 \mathrm{H}$-indole-3-carboxaldehyde, 4-hydroxy-1 $\mathrm{H}$-indole-3-carboxaldehyde, kaempferol, thevetiaflavone, tetrahydroquinoline, rutin, kaempferol-3-glucoside, kaempferol-3-rutinoside, kaempferol-3-rhamnorutinoside, isorhamnetin 3-O-rutinoside, quercetin 3-O-glucoside, ginkgetin, isoginkgetin, sakuranetin and glucocapparin in aerial parts. The main components of root are capparispine, cadabicine 26-O- $\beta$-D-glucoside, capparispine 26-O- $\beta$-Dglucoside, and stachydrine, seeds contain glucocapparin. Traditional application of caper is for treatment of headache, fever, convulsions, diabetes, toothache, menstruation, skin disease, kidney disease, liver disease, rheumatism, ulcers, hemorrhoids and sciatica. Fruit and leaves have anti-diabetic effects, fruits have anti-obesity, cholesterol-lowering and anti-hypertensive effects, roots, fruits, stem barks and shoots have antimicrobial effects, leaves, roots and fruits contain anti-inflammatory activity, and aerial parts have antihepatotoxic effects.
\end{abstract}

Conclusion: On the basis of phytochemical advantages and pharmacological benefits, caper shows its importance as one of the most notable medicinal plant for prevention and treatment of various diseases, however, more researches are need on the usage of caper, especially in modern pharmaceutical science.

Keywords: Caper, Traditional medicine, Pharmaceutical benefits, Capparis spinosa, Rutin

*Correspondence: hesamshahrajabian@gmail.com

${ }^{\dagger}$ Mohamad Hesam Shahrajabian and Wenli Sun have contributed equally

to this paper

1 Biotechnology Research Institute, Chinese Academy of Agricultural

Sciences, Beijing 100081, China

Full list of author information is available at the end of the article

\section{Background}

Medicinal plants knowledge has its origins in ancient civilizations, and cultures, and its main aim is to return the body to a state of natural balance with its active ingredients (Khoshkharam et al. 2021; Shahrajabian et al. 2021a,b). The main medification functions of medicinal herbs in traditional herbal sciences of countries like Iran, China, India and Japan have been received notable attentions in recent years (Marmitt 
and Shahrajabian 2021; Marmitt et al. 2021; Shahrajabian et al. 2021c,d). Traditional medicine, based largely on herbs, still supports the primary healthcare of more people worldwide than conventional or western medicine (Sun et al., 2021a,b), and they are culturally acceptable and readily available even in modern era (Shahrajabian et al. 2020a,b).

Capparis spinosa L. is a perennial plant typical of the Mediterranean flora and a multipurpose plant used for curing various human ailments (Panico et al. 2005), and its fresh and pickled flower buds were the most studied parts of the plant (Allaith 2016). Although, it is native to the Mediterranean but well grows in Italy, Northern Africa, Greece, Central Asia, Iran, and other parts of the world (Zarei et al. 2021). In traditional medicine and indigenous knowledge, roots are used as diuretic, astringent, and tonic; bark root used as appetizer, astringent, tonic, antidiarrheic and to treat hemorrhoids, and spleen disease; and bark is also used for gout and rheumatism, as expectorant, and for chest diseases. Caper favours a rainy spring and a dry, hot summer with intense sunlight where temperature exceeds $40{ }^{\circ} \mathrm{C}$ and average rainfall is $350 \mathrm{~mm}$ during spring and winter season (Barbera and Lorenzo 1984). Capparis spinosa is called the Plant of the Millennium, and it has highly diverse economic and medicinal value in different system of medicines like in Iranian, Unani, Chinese, Ayurvedic and Greco-Arabi system of medicines (Sher and Alyemeni 2010). The antioxidant activity of various parts of caper was reported from different scholars (Bonita et al. 2002; Yue-lan et al. 2010; Aliyazicioglu et al. 2013; Mazandarani et al. 2014; Kalantari et al. 2018). Caper seeds declared an important source of antioxidant molecules for the food and pharmaceutical industries as they are rich in phenolic compounds and show high antioxidant activity (Tlili et al. 2015). Caper seed is an inexpensive source of omega-6, and its seed oil is regarded as oleic-linolecic oil (Dursun and Dursun 2005; Mahdavi Ara et al. 2014). The consolidated traditional use of its root as remedy against different pains in human is well known since the antiquity (Khatib et al., 2016). Capparis spinosa contains bioactive lipids, glucosinolates and flavonoids, and seed oil is rich in unsaturated and rare lipids such as cis-vaccenic acid, and the main glucosinolate is glucocapperin, and the main flavonoid is rutin (Sharaf et al. 2000; Argentieri et al. 2012). The most important identified compounds are quercetin, kaempferol and isorhamnetin derivatives in addition to myricetin, eriodictyol, cirsimaritin and gallocatechin derivatives (Bakr and El Bishbishy 2016). This article is aimed to have a brief review on pharmaceutical benefits of caper in both traditional and modern medicinal sciences with considering its chemical constituents.

\section{Main text \\ Agronomic traits}

The Capparis spinoa L. is an important medicinal plant in the family Capparaceae, the complete cp genome of Capparis spinosa L. has 157,728 bp in length and contains 136 genes, and the plastome contained 80 protein coding genes, 31 tRNA genes and 4 rRNA genes (Alzahrani et al. 2021). This ancient plant is sensitive to salt stress at its primary growth phase, and applying biostimulant may increase plant biomass, proline, soil enzymes activity, increased rutin bioflavonoid of caper, and increased the phenol content of caper (Sadeghi and Taban 2021; Shahrajabian et al. 2021e,f). Caper fruits were characterized to have the exocarp green in all stages of development, and there was a decrease in the protein content with the development of the fruit, while the fruits presented high contents of total phenols, flavonoids and flavanols (Grimaly et al. 2018). The plant is a perennial winter deciduous species that bears founded, fleshy leaves and large white to pinkish flowers, it is a shrub with $30-50 \mathrm{~cm}$ height; the caper fruits names as cape berry and it is ellipsoid or ovate shape, and dry heat and intense sunlight make the preferred environment for caper plants. Quaternary ammonium compounds (QACs), as constituents of Capparaceae, play important roles in protecting against abiotic stress which can be found in both roots and leaves (Al-Tamimi et al. 2019). Fertilization induced an increase in productivity and nutrient tissue concentrations of both $\mathrm{N}$ and $\mathrm{P}$, and increased $\mathrm{K}$ and $\mathrm{Ca}$ uptake to maintain the hydric balance, thorny stems and a heavy investment in chemical defenses to prevent grazing, and a deep mycorrhizal root system allow Capparis to grown successfully in very infertile soils and to endure environmental stress (Pugnaire and Esteban 1991). Seeds soaked in sulphuric acid and in gibberellins solution, and then dried at room temperature to their original air-dry weight, germinated as well as non-dried seeds (Orphanos 1983). An analysis of caper variability in Tunisia using morphological descriptors revealed intra-specific diversity; two recognized morphotypes were (1) prickly and one that included the inermis and downy caper, and (2) the second one is characterized by creeping shoots and relatively large leaves, low stomatal density, and high numbers of stamens, and the heterogeneous prickly group is characterized by erect shoots and relatively small leaves, high stomatal density, and a small numbers of stamens (Saadaoui et al. 2009). The salient features of the growth mechanism of Capparis demonstrate a sophisticated plant response to drought, involving osmotic adjustment, regulated stomatal opening, cell wall properties and 
increased root density (Rhizopoulou 1990). Deep roots, with high tip water potentials, may sustain high plant water potentials (Rhizopoulou and Kapolas 2015). Stomata were found on the abaxial surface of sepals, and on both the adaxial and abaxial surfaces of petals, filaments and style were densely packed with small cells, exhibiting an increased density of cell wall material that provides strength, and petals possessed vacuolated parenchyma cells with large intercellular space (Rhizopoulou et al. 2006).

\section{Chemical constituents}

It has been reported that Capparis spinosa is a rich source, not only of sulphur compounds, but also with phenolic and flavonoid glycosides contributing to its powerful cytotoxic activity (Bakr and El Bishbishy 2016). Berries of Capparis spinosa possess carbohydrate content (5\%), dietary (3\%), protein (2\%), and lipids $(0.9 \%)$, and it contains moderate content of vitamin C (4 mg/100 g fw) (Allaith 2016). Qualitative phytochemical analysis of Capparis spinosa (aerial parts) extract, showed, alkaloids, glycosides, carbohydrates, tannins, phenols, and triterpenoids in ethanolic extract, and alkaloids, steroids, carbohydrates, flavonoids, tannins, phenols, and saponins in aqueous extract (Mustafa 2011). Tlili et al. (2011) reported that phytochemicals studies have shown the presence of many beneficial compounds such as spermidine, rutin, quercetin, kaempferol, stigmasterol, campesterol, tocopherols, and carotenoids. Glucocapparin is the main component in extracts of non-fermented berries and is fully degraded upon the fermentation process, and epicatechin amounts are lower and free quercetin is observed after the fermentation (Jimenez-Lopez et al. 2018). Linoleic and oleic acids were established as major fatty acids of seeds oils of caper seed (Capparis spinosa) (Ozcan et al. 2012). Elemental analysis values of Capparis spinosa $\mathrm{L}$. using EDXRF system are $\mathrm{Al}(0.48 \pm 0.05 \%), \mathrm{P}(1.15 \pm 0.01 \%)$, $\mathrm{S}(4.00 \pm 0.06 \%), \mathrm{K}(4.54 \pm 0.03 \%), \mathrm{Ca}(1.18 \pm 0.01 \%)$, $\mathrm{Cl} \quad(94.86 \pm 25.51 \quad \mathrm{ppm}), \quad \mathrm{Ti} \quad(55.24 \pm 2.30 \quad \mathrm{ppm})$, $\mathrm{Mn} \quad(70.04+1.00 \mathrm{ppm}), \quad \mathrm{Fe} \quad(520.72 \pm 4.05 \mathrm{ppm})$, $\mathrm{Ni}(24.10 \pm 0.05 \mathrm{ppm}), \quad \mathrm{Cu}(88.27 \pm 0.45 \mathrm{ppm}), \quad \mathrm{Zn}$ $(250.75 \pm 0.80 \mathrm{ppm}), \quad$ Br $\quad(11.92 \pm 0.07 \quad \mathrm{ppm}), \quad \mathrm{Rb}$ $(79.03 \pm 0.19 \mathrm{ppm}), \quad \mathrm{Sr}(40.20 \pm 0.69 \mathrm{ppm})$, and $\mathrm{Pb}$ $(5.34 \pm 0.13 \mathrm{ppm})$ (Aliyazicioglu et al. 2013). Constituents of the volatile oils of the leaf, ripe fruit and root of Capparis spinosa var. mucronifolia growing wild in Isfahan (Iran) were studied by TLC, GC and GC-MS methods, where the leaf oil was composed of isothiocyanates, $n$-alkanes, terpenoids, a phenyl propanoid, an aldehyde and a fatty acid, and the main components of the oil were thymol (26.4\%), isopropyl isothiocyanate (11\%), 2-hexenal (10.2\%), and butyl isothiocyanate (6.3\%), and the volatile oils of the ripe fruit and the root were composed mainly of the methyl, isopropyl and sec-butyl isothiocyanates (Afsharypuor et al. 1998). $p$-Methoxy benzoic acid isolated from the methanolic soluble fraction of the aqueous extract of Capparis spinosa was found to possess significant antihepatotoxic activity against carbontetrachloride and paracetamol induced hepatotoxicity in vivo and thioacetamide and galactosamine induced hepatotoxicity in isolated rat hepatocytes using in vitro technique (Gadgoli and Mishra 1999). The main phytoconstituents of Capparis spinosa are, flazin, guanosine, capparine A, capparine B, $1 \mathrm{H}$-indole-3-carboxaldehyde, 4-hydroxy-1H-indole-3-carboxal-dehyde, chrysoeriol, apigenin, kaempferol, thevetia-flavone, 5-hydroxymethylfuraldehyde, vanillic acid and cinnamic acid in fruits; cappariside or 4-hydroxy-5-methylfuran-3-carboxylic acid, 5-hydroxymethylfurfural, 5-hydroxymethyl furoic acid, and 2-furoic acid in whole plant; protocatechuic aldehyde, E-butenedioic acid, ethyl 3,4-dihydroxybenzoate, syringic acid, protocatechuic acid, vanillic acid, succinic acid, 4-hydroxybenzoic acid and $\alpha$-tocopherol in fruits; rutin in aerial parts such as leaves, buds and flowers, and homogalacturonan in fruits (Moufid et al. 2015). Investigation of Capparis spinosa of Jordanian origin lead to isolation of two new compounds g-sitosterylglucoside-6 $6^{\prime}$-octadecanoate (1) and 3-menthyl-2-butenylg-glucoside (2) (Khanfar et al. 2003). Three extraction methods, involving maceration, reflux, and ultrasonic extractions were used to evaluate the phytochemical content and antioxidant activity of leaf extracts from Capparis spinosa L. collected from five localities in South Tunisia; the maceration extraction method exhibited the highest antioxidant activities using the reducing power assay, the azinobis (3-ethylbenzothiazoline)-6-sulfonic acid $\left(\mathrm{ABTS}^{+}\right)$, and the 2,2-diphenul-1-picrylhydrazyle $\left(\mathrm{DPPH}^{\circ}\right)$ radical scavenging activity; also, the major identified phenolic acids were quinic acid, gallic acid, and protocatchuic acid, and catechin was the most abundant flavonoid in all detected extracts (Yahia et al. 2020). HPLC analysis showed high levels of rutin and quercetin in leaves of Capparis, rutin was 16,939.2 \pm 0.01 and quercetin was $908.93 \pm 0.01 \mu \mathrm{g} / \mathrm{g}$ fresh weight, and in fruit, $1019.52 \pm 0.01$ rutin and $97.86 \pm 0.01 \mu \mathrm{g} / \mathrm{g} F W$ quercetin were measured (Mohebali et al. 2018). Three new alkaloids, capparisine A (1), capparisine B (2), capparisine $C$ (3), and two known alkaloids, 2-(5-hydroxymethyl-2-formylpyrrol-1-yl) propionic acid lactone (4), and $\mathrm{N}$-(3'-maleimidyl)-5-hydroxymethyl-2-pyrrole formaldehyde (5) were isolated from the fruits of C. spinosa L. (Yang et al. 2010). In Algeria, the result of chromatographic analysis (CG/MS) leads to the identification of 33 components; palmitic acid (38.19\%), nonanal-n (12.61\%), cymene-2,5-dimethoxy-para (8.94\%), and octacosane 
(5.49\%) which were the major components of essential oil (Benachour et al. 2020). Aliphatic acids and aldehydes are the most abundant chemical classes in samples from Pantelleria and Salina Islands in Italy, and among sulfur compound, methyl-isothiocyanate is the major one, followed by benzyl-isothiocyanate (Condurso et al. 2016). In one experiment in Turkey, the major volatile compounds found in caper bud oil were benzyl alcohol (20.4\%), furfural (7.4\%), ethanol methyl pentyl acetal (5.9\%), 4-vinyl guaiacol (5.3\%), thymol (5.1\%), octanoic acid $(4.8 \%)$, and methyl isothiocyanate (4.5\%), while the major volatile compounds found in caper leaves were methyl isothiocyanate (20.0\%), thymol (15.5\%), 4-vinyl guaiacol (4.3\%), hexyl acetate (3.6\%), and trans-theaspirane (2.6\%) (El-Ghorab et al. 2007). The higher phenolic content was determined in the fresh $(1843.71 \mathrm{mg} / 100 \mathrm{~g}$ DW), and fermented buds (1198.54-1539.49 mg/100 g DW) rather than the berries $(29.72-40.75 \mathrm{mg} / 100 \mathrm{~g}$ DW); quercetin-3-O-rutinoside, kaempferol-3-O-rutinoside, and quercetin-O-galloly-O-hexoside were the principal phenolic components in fresh and fermented buds while quercetin-3-O-rutinoside in fresh and fermented berries (Aksay et al. 2021). The occurrence of glucobrassicin, neoglucobrassicin and 4-methoxy-glucobrassicin in roots of Capparis spinosa is demonstrated by HPLC and mass spectral methods (Schraudolf 1989). Francesca et al. (2016) reported that high-performance liquid chromatography/electrospray ionization source/ mass spectrometry (HPLC-ESI-MS) successfully identified 9 polyphenols, epicatechin was found in untreated fruits, and quercetin in processed caper berries. Three new alkaloids capparispine (1), capparispine 26-O- $\beta$-Dglucoside (2), and cadabicine $26-O-\beta$-D-glucoside hydrochloride (3) were isolated from the roots of C. spinosa in Xinjiang Uighur Autonomous Region, China (Fu et al. 2008). Quercetin content in different parts of caper are $1.7 \mathrm{mg} / \mathrm{g}$ in root, $5 \mathrm{mg} / \mathrm{g}$ in stem, $7.92 \mathrm{mg} / \mathrm{g}$ in the leaf, $10 \mathrm{mg} / \mathrm{g}$ in floral bud, $12.8 \mathrm{mg} / \mathrm{g}$ in flower, $9.6 \mathrm{mg} / \mathrm{g}$ in fruit and $6.2 \mathrm{mg} / \mathrm{g}$ in the seed (Moghaddasian et al. 2012).

\section{Traditional medicinal benefits}

Caper is a traditionally used medicinal plant and widely studied for its biological properties. Moroccan sample showed the highest phenolic content across all extraction types followed by Italian and Turkish (Stefanucci et al. 2018). A traditional Persian medicine formulation for diabetes mellitus are Capparis spinosa, Rosa canina, Securidaca securigera, Silybum marianum, Urtica dioica, Trigonella foenum-graecum, and Vaccinium arctostaphyls with no notable hepatic, renal and gastrointestinal side effects (Mehrzadi et al. 2021). In Greek popular medicine, a herbal tea made of caper root and young shoots is considered to be beneficial against rheumatism (Mohammad et al. 2012). Many parts of caper are still being used as drugs and traditional healers in Saudi Arabia describe oral administration of dried fruits of Capparis spinosa $\mathrm{L}$. with water to treat hypertension and diabetic complication (Sher and Alyemeni 2010). In Bahrain, fresh caper berries are still eaten by the elderly, whereas in Eastern India, fresh raw caper berries are consumed as an appetizer. Seed clumps of Capparis spinosa L. together with shoots, leaves and fruits has been used in eastern part of Central Asia for medicinal purposes (Jiang et al. 2007). A decoction of Capparis spinosa L. roots, widely used in traditional folk medicine of southern Italy, and heterocyclic compounds were also recovered from the chloroformic extract of the roots, and it showed an interesting bacteriostatic activity on the growth of Deinococcus radiophilus (Boga et al. 2011). The antioxidant, nephroprotective and hepatoprotective effects of methanolic extract of its leaves associated with its phytochemical content, and nine compounds namely rutin, resveratrol, coumarin, epicatechin, luteolin, catechin, kaempferol, vanillic acid and gallic acid are more responsible in support of traditional usage of Capparis spinosa to cure kidney and liver diseases (Tlili et al. 2017). In traditional medicinal science, the whole plant was used for rheumatism, roots were used as diuretic, astringent, and tonic, bark root, which has bitter taste, was used as appetizer, astringent, tonic, anti-diarrheic and to treat hemorrhoids and spleen diseases, infusion of stems and root bark were used as anti-diarrheic and febrifuge, fresh fruits were used in sciatica and dropsy, and dried and powdered fruit combined with honey was used in colds, rheumatism, gout, sciatica and backache (Rahnacard and Razavi 2017).

\section{Modern pharmaceutical benefits}

Capparis spinosa L. has the potential to down regulate inflammation-involved genes in Alzheimer's disease (AD), due to its high levels of flavonoids and could be beneficial as a dietary complement in AD patients (Mohebali et al. 2018). Capparis species specially C. spinosa and $C$. decidua are cultivated commercially and being used in food industries, and Capparis species are rich sources of antioxidant and bioactive compounds being responsible for various biological activities (Gull et al. 2015). It has been reported that the methanol extract of Capparis (MEC) has antinociceptive effects both at the peripheral and central levels (Arslan et al. 2010). Phytochemical analysis shows that Capparis spinosa has high quantities of bioactive constituents, including polyphenolic compounds, which are responsible for its health-promoting effects. The aqueous extract of Capparis spinosa $\mathrm{L}$. $(20 \mathrm{mg} / \mathrm{kg})$ exhibits a potent lipid lowering activity in both normal and severe hyperglycemic rats after repeated oral administration of its aqueous extract 
(Eddouks et al. 2005). The total antioxidant capacity assessed using the molybdate assay ranged between $99.54 \pm 0.90 \mathrm{mg}$ AAE (ascorbic acid equivalent)/g in Capparis spinosa pollen (Bakour et al. 2020). Synthesis of $\mathrm{CuO}$ nanoparticles from Capparis spinosa is reported (Samari et al. 2019). The methanolic extract of C. spinosa L. demonstrated anti-quorum sensing (QS) and anti-biofilm activity at $0.5-2 \mathrm{mg} / \mathrm{mL}$ (Abraham et al. 2011). The antioxidant effect of leaf extract of Capparis spinosa is six times greater than fruit, and the use of leaf extract or its active metabolites in the sperm culture medium may be beneficial for maintaining motility, vitality and sperm DNA (Khojasteh Rad et al. 2021). Antioxidant capacities strongly correlated with the total free phenolics, total flavonoids, and total carotenoids (Allaith 2016). The Capparis spinosa leaves can be used as a potential, low-cost source of polysaccharide, and the polysaccharides of leaves exhibited significant antioxidant activity; furthermore, a much more antimicrobial activity using the polysaccharide against Gram-negative bacteria (Escherichia coli, Shigella dysenteriae and Salmonella typhi) was found than Gram-positive bacteria (Bacillus panis and Staphylococcus aureus) (Mazarei et al. 2017). Methyl isothiocyanate was detected as major volatile compounds in caper essential oil, rutin and chlorogenic acid were detected as dominant compounds in caper aqueous infusion which induced to high-inhibitory effect of oil and infusion on HT-29 cell proliferation and NF- $\mathrm{kB}$ activation also caper oil and infusion blocked the cell cycle at $G_{2} / M$ phase which suggest that both volatile and non-volatile compounds of caper potentially can play an important role in colon cancer prevention (Kulisic-Bilusic et al. 2012). Biodiesel was produced from novel non-edible caper seed oil, and biodiesel showed excellent potential as a sustainable and renewable source of bioenergy (Munir et al. 2021). Capparis spinosa reduced brain inflammation, improved LPS-induced cognitive impairment, and by in vivo, C. spinosa polarized inflammatory microglial cells towards M2, and by in vitro assay, C. spinosa directly shifts lipopolysaccharide (LPS)-induced M1/ M2 imbalanced towards M2 cells (Rahimi et al. 2020). The anti-inflammatory, antiarthritic, and anti-thrombotic activities of methanol extract of Capparis buds, leaves, stems and fruits has been reported in other studies (Bektas et al. 2012; Ozgun-Acar et al. 2016; Twumasi et al. 2019). Caper extract at $0.1 \mathrm{~g} \mathrm{~kg}^{-1}$ feed proved to be a potential immunostimulant for fish (Bilen et al. 2016). Eddouks et al. (2004) reported that the oral administration of the aqueous extract of Capparis spinosa L. fruit $(20 \mathrm{mg} / \mathrm{kg}$ ) produced a significant decrease on blood glucose levels in streptozotocin (STZ) diabetic rats; the blood glucose levels were nearly normalized 2 weeks after daily repeated oral administration of it, which can be selected as a potent anti-hyperglycaemic activity in STZ rats without affecting basal plasma insulin concentration. It has been reported that small caper berries had higher, crude protein, phenolic compounds and flavonoids than the big one (El Amri et al. 2019). Biochemical analysis showed nephroprotective and hepatoprotective effects of methanol extracts of Capparis spinosa seeds, and histopathologial study suggested that the extracts protect against tissues fibrosis (Tir et al. 2019). The regular administration of Capparis spinosa leaf or buds normalized all the biochemical parameters and reversed the liver/kidney injury with variable degrees of organ protection, because of antidiabetic and antihyperlipidemic effects of it (Mollica et al. 2017). The putative mechanisms involved in the antihyperglycemic effects of Capparis spinosa include reducing carbohydrate absorption from the small intestine, inhibiting gluconeogenesis in the liver, enhancing glucose uptake by tissues, and beta cell protection/regeneration (Vahid et al. 2017). Antioxidant capacities of caper berries strongly correlated with the total free phenolics, total flavonoids, and total carotenoids. Capparis spinosa extracts relieved pain related to rheumatoid arthritis and osteoarthritis after single administration (Maresca et al. 2016). Capparis spinosa improved the circulating levels of triglyceride and cholesterol, and direct inhibition of gluconeogenesis in liver maybe a probable mechanism of action of this plant, and its administration might be a beneficial therapeutic approach for metabolic syndrome and fatty liver (Jalali et al. 2016). Systematic use of Capparis spinosa extract may accelerate bone formation at the expanded suture in rats (Erdogan et al. 2015). Caper fruit extract may be a safe anti-hyperglycemic and anti-hypertriglyceridemic agent for type 2 diabetic patients, with no liver, kidney and other side effects (Fallah Huseini et al. 2013). The ethanolic root bark extract of C. spinosa could afford significant dose-dependent protection against $\mathrm{CCl}_{4}$ induced hepatocellular injury (Aghel et al. 2007). The hydro-ethanolic extract of Capparis spinosa (HECS) significantly decreased hepatic phosphoenolpyruvate carboxykinase, increased acetyl CoA carboxylase and non-significantly decreased hepatocyte nuclear factor- $4 \alpha$ (HNF- $4 \alpha$ ) as a transactivator of phosphoenolypyruvate carboxykinase (PEPCK) at mRNA expression level in diabetic rats (Assadi et al. 2021). Manikandaselvi et al. (2018) reported the strong antioxidant activity in aqueous extract centered on the outcomes of DPPH radical scavenging (IC-50 $1.74 \mu \mathrm{g} / \mathrm{ml}$ ), and inhibition of lipid peroxidation (IC-50 $4.01 \mu \mathrm{g} / \mathrm{ml}$ ) assays; and the aqueous extract exhibited anti-inflammatory activity in terms of inhibition of protein denaturation (IC-50 $8.01 \mu \mathrm{g} / \mathrm{ml}$ ), inhibition of protease activity (14.24\%), and RBC membrane stabilization (IC-50 $226.69 \mu \mathrm{ml}$ ), and also possess antibacterial 
activity against Bacillus cereus, Staphylococcus aureus, Campylobacter jejuni, and Salmonella enteritidis strains. Capparis spinosa fruit extract could be aid prevention of damage to the tissues due to the decreased levels of harmful oxidants in the body in diabetes (Taghavi et al. 2014).

\section{Conclusion}

Natural products such as medicinal and aromatic plants have been used as traditional remedies because of their amazing healing characteristics. Caper (Capparis spinosa L.) is one of the most important medicinal plant in Iranian, Chinese, Unani, Ayurvedic and Greco-Arabi medicinal systems. The phytochemicals identified in this plan were lipids, flavonoids, alkaloids, saponins, tannins, lignins, glucocapperin, (6S)-hydroxy-3-oxo$\alpha$-ionolglucosides and polyphenols. Capparis spinosa has anthelminthic, cytotoxic, anti-inflammatory, antiarthritic, anti-oxidant, anti-microbial, cardiovascular, chondroprotective, anti-diabetic, hypolipidemic, antiallergic, anti-histaminic, immunemodulatory, anti-carcinogenic and anti-hepatotoxic activities. Caper can be recommended for more clinical experiments to evaluate its clinical efficacy and safety in modern pharmaceutical science by considering its chemical constituents.

\footnotetext{
Abbreviations

QACs: Quaternary ammonium compounds; ABTS ${ }^{+}$: The azinobis

(3-ethylbenzothiazoline)-6-sulfonic acid; DPPH ${ }^{\circ}$ : The 2,2-diphenul-1-picrylhydrazyle; HPLC: High-performance liquid chromatography; CG/MS: Chromatographic analysis; HPLC-ESI-MS: The high-performance liquid chromatography/ electrospray ionization source/mass spectrometry; AD: Alzheimer's disease; MEC: Methanol extract of Capparis; AAE: Ascorbic acid equivalent; QS: Anti-quorum; LPS: Lipopolysaccharide; STZ: Streptozotocin; HECS: Streptozotocin (STZ), the hydro-ethanolic extract of Capparis spinosa; HNF-4a: Hepatocyte nuclear factor-4a; PEPCK: Transactivator of phosphoenolypyruvate carboxykinase.
}

\section{Acknowledgements}

Not applicable.

\section{Authors' contribution}

M.H.S.: Writing-original draft preparation; W.S.: Writing-original draft preparation; Q.C.: Writing-review and editing. All authors have read and approved to the manuscript.

\section{Funding}

This project was supported by the Natural Science Foundation of Beijing China (Grant No. M21026). Expense for this research work was provided to faculty members of Biotechnology Research Institute, Chinese Academy of Agricultural Sciences in Beijing, China.

\section{Availability of data and materials}

Not applicable.

\section{Declarations}

Ethics approval and consent to participate Not applicable.

\section{Consent for publication}

Not applicable.

\section{Competing interests}

The authors declare that they have no potential conflicts of interest.

\section{Author details}

${ }^{1}$ Biotechnology Research Institute, Chinese Academy of Agricultural Sciences, Beijing 100081, China. ${ }^{2}$ College of Life Sciences, Hebei Agricultural University, Baoding 071000, Hebei, China. ${ }^{3}$ Global Alliance of HeBAU-CLS\&HeQiS for BioAl-Manufacturing, Baoding 071000, Hebei, China.

Received: 24 June 2021 Accepted: 16 July 2021

Published online: 22 July 2021

\section{References}

Abraham SVPI, Palani A, Ramaswamy BR, Shunmugiah KP, Arumugam VR (2011) Antiquorum sensing and antibiofilm potential of Capparis spinosa. Arch Med Res 42(8):658-668. https://doi.org/10.1016/j.arcmed.2011.12. 002

Afsharypuor S, Jeiran K, Arefian Jazy A (1998) First investigation of the flavour profile of the leaf, ripe fruit and root of Capparis spinosa var. mucronifolia from Iran. Pharm Acta Helv 72(5):307-309. https://doi.org/10.1016/s00316865(97)00023-x

Aghel N, Rashidi I, Mombeini A (2007) Hepatoprotective activity of Capparis spinosa root bark against $\mathrm{CCl}_{4}$ induced hepatic damage in mice. Iran J Pharm Sci 6(4):285-290

Aksay O, Selli S, Kelebek H (2021) LC-DAD-ESI-MS/MS-based assessment of the bioactive compounds in fresh and fermented caper (Capparis spinosa) buds and berries. Food Chem 337:127959. https://doi.org/10.1016/j.foodc hem 2020.127959

Al-Tamimi A, Khatib M, Pieraccini G, Mulinacci N (2019) Quaternary ammonium compounds in roots and leaves of Capparis spinosa L. from Saudi Arabia and Italy: investigation by HPLC-MS and 1HNMR. Nat Prod Res 33(9):1322-1328. https://doi.org/10.1080/14786419.2018.1475376

Aliyazicioglu R, Eyupoglu OE, Sahin H, Yildiz O, Baltas N (2013) Phenolic components, antioxidant activity, and mineral analysis of Capparis spinosa $\mathrm{L}$. Afr J Biotechnol 12:6643-6649. https://doi.org/10.5897/ajb2013.13241

Allaith AAA (2016) Assessment of the antioxidant properties of the caper fruit (Capparis spinosa L.) from Bahrain. J Assoc Arab Univ Basic Appl Sci 19:1-7. https://doi.org/10.1016/j.jaubas.2014.07.001

Alzahrani D, Albokhari E, Yaradua S, Abba A (2021) The complete plastome sequence of the medicinal species Capparis spinosa L. (Capparaceae). Gene Rep 23:101059. https://doi.org/10.1016/j.genrep.2021.101059

Argentieri M, Macchia F, Papadia P, Fanizzi FP, Avato P (2012) Bioactive compounds from Capparis spinosa subsp. rupestris. Ind Crops Prod 36(1):65-69. https://doi.org/10.1016/j.indcrop.2011.08.007

Arslan R, Bektas N, Ozturk Y (2010) Antinociceptive activity of methanol extract of fruits of Capparis ovata in mice. J Ethnopharmacol 131(1):28-32. https://doi.org/10.1016/j.jep.2010.05.060

Assadi S, Shafiee SM, Erfani M, Akmali M (2021) Antioxidative and antidiabetic effects of Capparis spinosa fruit extract in high-fat diet and low-dose streptozotocin-induced type 2 diabetic rats. Biomed Pharmacother 138:111391. https://doi.org/10.1016/j.biopha.2021.111391

Bakour M, Campos MDG, Imtara H, Lyoussi B (2020) Antioxidant content and identification of phenolic/flavonoids compounds in the pollen of fourteen plants using HPLC-DAD. J Apic Res 59(1):35-41. https://doi.org/ 10.1080/00218839.2019.1675336

Bakr RO, El Bishbishy M (2016) Profile of bioactive compounds of Capparis spinosa var. aegyptiaca growing in Egypt. Rev Bras de Farmacogn 26(4):514-520. https://doi.org/10.1016/j.bjp.2016.04.001

Barbera G, Di Lorenzo R (1984) The caper culture in Italy. Acta Hortic 144:167171. https://doi.org/10.17660/actahortic.1984.144.21

Bektas N, Arslan R, Goger F, Kirimer N, Ozturk Y (2012) Investigation for antiinflammatory and anti-thrombotic activities of methanol extract of Capparis ovata buds and fruits. J Ethnopharmacol 142(1):48-52. https:// doi.org/10.1016/j.jep.2012.04.011

Benachour H, Ramdani M, Lograda T, Chalard P, Figueredo G (2020) Chemical composition and antibacterial activities of Capparis spinosa essential 
oils from Algeria. Biodiversitas 21(1):161-169. https://doi.org/10.13057/ biodiv/d21021

Bilen S, Altunoglu YC, Ulu F, Biswas G (2016) Innate immune and growth promoting response to caper (Capparis spinosa) extract in rainbow trout (Oncorhynchus mykiss). Fish Shellfish Immunol 57:206-212. https://doi. org/10.1016/j.fsi.2016.08.040

Boga C, Forlani L, Calienni R, Hindley T, Hochkoeppler A, Tozzi S, Zanna N (2011) On the antibacterial activity of roots of Capparis spinosa L. Nat Prod Res 25(4):417-421. https://doi.org/10.1080/14786419.2010.487189

Bonita F, Puglia C, Ventura D, Aquino R, Tortora S, Sacchi A, Saija A, Tomaino A, Pellegrino ML, De Capraris P (2002) In vitro antioxidant and in vivo photoprotective effects of a lyophilized extract of Capparis spinosa L. buds. J Cosmet Sci 53:321-335

Condurso C, Mazzaglia A, Tripodi G, Cincotta F, Dima G, Lanza CM, Verzera A (2016) Sensory analysis and head-space aroma volatiles for the characterization of capers from different geographic origin. J Essen Oil Res 28(3):185-192. https://doi.org/10.1080/10412905.2015.1113205

Dursun E, Dursun I (2005) Some physical properties of caper seed. Biosyst Eng 92(2):237-245. https://doi.org/10.1016/j,biosystemsend.2005.06.003

Eddouks M, Lemhadri A, Michel J-B (2004) Caraway and caper: potential antihyperglycaemic plants in diabetic rats. J Ethnopharmacol 94(1):143-148. https://doi.org/10.1016/j.jep.2004.05.006

Eddouks M, Lemhadri A, Michel J-B (2005) Hypolipidemic activity of aqueous extract of Capparis spinosa L. in normal and diabetic rats. J Ethnopharmacol 98(3):345-350. https://doi.org/10.1016/j.jep.2005.01.053

El Amri N, Errachidi F, Bour A, Chabir R (2019) Characterization of Moroccan raw and processed caper berries. Mater Today 13(3):841-849. https://doi. org/10.1016/j.matpr.2019.04.047

El-Ghorab A, Shibamoto T, Ozcan MM (2007) Chemical composition and antioxidant activities of buds and leaves of capers (Capparis ovata Desf. Var. canescens) cultivated in Turkey. J Essent Oil Res 19(1):72-77. https:// doi.org/10.1080/10412905.2007.9699233

Erdogan MS, Babacan H, Kara MI, Gurler B, Akgul H, Soyler DA (2015) Effect of Capparis spinosa extract on sutural ossification: a stereological study. Arch Oral Biol 60(8):1146-1152. https://doi.org/10.1016/j.archoralbio.2015.04. 012

Fallah Huseini H, Hasani-Rnjbar S, Nayebi N, Heshmat R, Sigaroodi FK, Ahvazi M, Alaei BA, Kianbakht S (2013) Capparis spinosa L. (Caper) fruit extract in treatment of type 2 diabetic patients: a randomized double-blind placebo-controlled clinical trial. Complement Ther Med 21(5):447-452. https://doi.org/10.1016/j.ctim.2013.07.003

Francesca N, Barbera M, Martorana A, Saiano F, Gaglio R, Aponte M, Moschetti G, Settanni L (2016) Optimized method for the analysis of phenolic compounds from caper (Capparis spinosa L.) berries and monitoring of their changes during fermentation. Food Chem 196:1172-1179. https:// doi.org/10.1016/j.foodchem.2015.10.045

Fu XP, Wu T, Abdurahim M, Su Z, Hou XL, Aisa HA, Wu H (2008) New spermidine alkaloids from Capparis spinosa roots. Phytochem Lett 1(1):59-62. https://doi.org/10.1016/j.phytol.2008.01.001

Gadgoli C, Mishra SH (1999) Antihepatotoxic activity of $p$-methoxy benzoic acid from Capparis spinosa. J Ethnopharmacol 66(2):187-192. https://doi. org/10.1016/a0378-8741(98)00229-3

Grimaly M, Hernandez F, Legua P, Almansa MS, Amoros A (2018) Physicochemical composition and antioxidant activity of three Spanish caper (Capparis spinosa L.) fruit cultivars in three stages of development. Sci Hortic 240:509-515. https://doi.org/10.1016/j.scienta.2018.06.061

Gull T, Anwar F, Sultana B, Alcayde MAC, Nouman W (2015) Capparis species: a potential source of bioactives and high-value components: a review. Ind Crops Prod 67:81-96. https://doi.org/10.1016/j.indcrop.2014.12.059

Jalali MT, Mohammadtaghvaei N, Larky DA (2016) Investigation the effects of Capparis spinosa on hepatic gluconeogenesis and lipid content in streptozotocin-induced diabetic rats. Biomed Pharmacother 84:12431248. https://doi.org/10.1016/j.biopha.2016.10.061

Jiang H-E, Li X, Ferguson DK, Wang Y-F, Liu C-J, Li C-S (2007) The discovery of Capparis spinosa L. (Cpparidaceae) in the Yanghai Tombs (2800 years BP), NW China, and its medicinal implications. J Ethnopharmacol 113(3):409-420

Jimenez-Lopez J, Ruiz-Medina A, Ortega-Barrales P, Llorent-Martinez EJ (2018) Phytochemical profile and antioxidant activity of caper berries (Capparis spinosa $\mathrm{L}$.): evaluation of the influence of the fermentation process. Food Chem 250:54-59. https://doi.org/10.1016/j.foodchem.2018.01.010
Kalantari H, Foruozandeh H, Khodayar MJ, Siahpoosh A, Saki N, Kheradmand P (2018) Antioxidant and hepatoprotective effects of Capparis spinosa L. fractions and quercetin on tert-butyl hydroperoxide- nduced acute liver damage in mice. J Tradit Complement Med 8:120-127. https://doi.org/10. 1016/j.jtcme.2017.04.010

Khanfar MA, Sabri SS, Abu Zarga MH, Zeller K-P (2003) The chemical constituents of Capparis spinosa of Jordanian origin. Nat Prod Res 17(1):9-14. https://doi.org/10.1080/10575630290034302

Khatib M, Pieraccini G, Innocenti M, Melani F, Mulinacci N (2016) An insight on the alkaloid content of Capparis spinosa L. root by HPLC-DAD-MS, MS/ MS and ${ }^{1} \mathrm{H}$ q NMR. J Pharma Biomed Anal 123:53-62. https://doi.org/10. 1016/j.jpba.2016.01.063

Khojasteh Rad M, Ghani A, Ghani E (2021) In vitro effects of Capparis spinosa L. extract on human sperm function, DNA fragmentation, and oxidative stress. J Ethnopharmacol 269:113702. https://doi.org/10.1016/j.jep.2020. 113702

Khoshkharam M, Shahrajabian MH, Esfandiary M (2021) The effects of methanol and amino acid glycine betaine on qualitative characteristics and yield of sugar beet (Beta vulgaris L.) cultivars. Not Sci Biol 13(2):1-13. https://doi.org/10.15835/nsb13210949

Kulisic-Bilusic T, Schmoller I, Schnabele K, Siracusa L, Ruberto G (2012) The anticarcinogenic potential of essential oil and aqueous infusion from caper (Capparis spinosa L.). Food Chemi 132(1):261-267. https://doi.org/ 10.1016/j.foodchem.2011.10.074

Mahdavi Ara K, Karami M, Raofie F (2014) Application of response surface methodology for the optimization of supercritical carbon dioxide extraction and ultrasound-assisted extraction of Capparis spinosa seed oil. J Supercrit Fluids 85:173-182. https://doi.org/10.1016/j.supflu.2013.10.016

Manikandaselvi S, Brindha P, Vadivel V (2018) Pharmacognostic and pharmacological studies on flower buds of Capparis spinosa L. Int J Pharm Qual Assur 9(3):246-252. https://doi.org/10.25258/ijpqa.v9i3.13655

Maresca M, Micheli L, Di Cesare ML, Tenci B, Innocenti M, Khatib M, Mulinacci N, Ghelardini C (2016) Acute effect of Capparis spinosa root extracts on rat articular pain. J Ethnopharmacol 193:456-465. https://doi.org/10.1016/j. jep.2016.09.032

Marmitt DJ, Shahrajabian MH (2021) Plant species used in Brazil and Asia regions with toxic properties. Phytother Res 2:1-24. https://doi.org/10. 1002/ptr.7100

Marmitt DJ, Shahrajabian MH, Goettert MI, Rempel C (2021) Clinical trials with plants in diabetes mellitus therapy: a systematic review. Expert Rev Clin Pharmacol 14(4):1-14. https://doi.org/10.1080/17512433.2021.1917380

Mazandarani M, Borhani G, Fathiazad F (2014) Phytochemical analysis, antioxidant activity and ecological requirements of Capparis spinosa $\mathrm{L}$. in Golestan and Semnan province (North of Iran). J Medicinal Plant byProducts 1:21-26. https://doi.org/10.3390/nu10020116

Mazarei F, Jooyandeh H, Noshad M, Hojjati M (2017) Polysaccharide of caper (Capparis spinosa L.) leaf: Extraction optimization, antioxidant potential and antimicrobial activity. Int J Biol Macromol 95:224-231. https://doi. org/10.1016/j.jibiomac.2016.11.049

Mehrzadi S, Mirzaei R, Heydari M, Sasani M, Yaqoobvand B, Huseini HF (2021) Efficacy and safety of a traditional herbal combination in patients with type II diabetes mellitus: a randomized controlled trial. J Diet Suppl 18(1):31-43. https://doi.org/10.1080/19390211.2020.1727076

Moghaddasian B, Eradatmand Asli D, Alaghemand A (2012) Quantitative analysis of quercetin in different parts of Capparis spinosa by HPLC. Ann Biol Res 3(12):5775-5778

Mohammad SM, Kashani HH, Azarbad Z (2012) Capparis spinosa L. propagation and medicinal uses. Life Sci J 9(4):684-686

Mohebali N, Shahzadeh Fazeli SA, Ghafoori H, Farahmand Z, MohammadKhani E, Vakhshiteh F, Ghamarian A, Farhangniya M, Sanati MH (2018) Effect of flavonoids rich extract of Capparis spinosa on inflammatory involved genes in amylod-beta peptide injected rat model of Alzheimer's disease. Nutri Neurosci 21(2):143-150. https://doi.org/10.1080/1028415x.1238026

Mollica A, Zengin G, Locatelli M, Stefanucci A, Mocan A, Macedonio G, Carradori S, Onaolapo O, Onaolap A, Adegoke J, Olaniyan M, Aktumsek A, Novellino E (2017) Anti-diabetic and anti-hyperlipidemic properties of Capparis spinosa L.: in vivo and in vitro evaluation of its nutraceutical potential. J Funct Foods 35:32-42. https://doi.org/10.1016/j.jff.2017.05. 001 
Moufid A, Faid P, Eddouks M (2015) Pharmacological properties of Capparis Spinosa Linn. Int J Diabetol Vasc Dis Res 3(5):99-104. https://doi.org/10. 19070/2328-353x-1500020

Munir M, Ahmad M, Saeed M, Waseem A, Nizami A-S, Sultana S, Zafar M, Rehan M, Srinivasan GR, Ali AM, Ali MI (2021) Biodiesel production from novel non-edible caper (Capparis spinosa L.) seeds oil employing Cu-Ni droped $\mathrm{ZrO}_{2}$ catalyst. Renew Sustain Energy Rev 138:110558. https://doi.org/10, 1016/j.rser.2020.110558

Mustafa FAA (2011) In vitro evaluation of Capparis spinosa against Lumbricus terrestris (Annelida). PUJ 5(2):199-202

Orphanos PI (1983) Germination of caper (Capparis spinosa L.) seeds. J Hortic Sci 58(2):267-270. https://doi.org/10.1080/002211589.1983.11515119

Ozcan MM, Endes GKZL, Er F (2012) Fatty acid compositions of some oil bearing plant seeds. Anal Chem Lett 2(4):235-239. https://doi.org/10.1080/ 22297928.2012.10648274

Ozgun-Acar O, Celik-Turgut G, Gazioglu I, Kolak U, Ozbal S, Ergur BU, Arslan S, Sen A, Topcu G (2016) Capparis ovata treatment suppresses inflammatory cytokine expression and ameliorates experimental allergic encephalomyelitis model of multiple sclerosis in C57BL/6 mice. J Neuroimmunol 298:106-116. https://doi.org/10.1016/j.jneuroim.2016.07.010

Panico AM, Cardile V, Garufi F, Puglia C, Bonina F, Ronsisvalle G (2005) Protective effect of Capparis spinosa on chondrocytes. Life Sci 77(20):2479-2488. https://doi.org/10.1016/j.lfs.2004.12.051

Pugnaire FI, Esteban E (1991) Nutritional adaptations of caper shrub (Capparis ovata Desf.) to environmental stress. J Plant Nutr 14(2):151-161. https:// doi.org/10.1080/01904169109364191

Rahimi VB, Rajabian A, Rajabi H, Mohammadi Vosough E, Mirkarimi HR, Hasanpour M, Iranshahi M, Rakhshandeh H, Askari VR (2020) The effects of hydro-ethanolic extract of Capparis spinosa (C. spinosa) on lipopolysaccharide (LPS)-induced inflammation and cognitive impairment: evidence from in vivo and in vitro studies. J Ethnopharmacol 256:112706. https:// doi.org/10.1016/j.jep.2020.112706

Rahnacard R, Razavi N (2017) A review on the medical effects of Capparis spinosa L. Adv Herb Med 3(1):44-53

Rhizopoulou S (1990) Physiological responses of Capparis spinosa L. to drought. J Plant Physiol 136(3):341-348. https://doi.org/10.1016/s01761617(11)80060-x

Rhizopoulou S, Kapolas G (2015) In situ study of deep roots of Capparis spinosa $\mathrm{L}$. during the dry season: evidence from a natural rhizotron in the ancient catacombs of Milos Island (Greece). J Arid Environ 119:27-30. https://doi. org/10.1016/j.jaridenv.2015.03.010

Rhizopoulou S, loannidi E, Alexandredes N, Argiropoulos A (2006) A study on functional and structural traits of the nocturnal flowers of Capparis spinosa L. J Arid Environ 66(4):635-647. https://doi.org/10.1016/j.jaridenv. 2005.12.009

Saadaoui E, Khaldi A, Khouja ML, Mohamed EG (2009) Intra-specific variation of Capparis spinosa L. in Tunisia. J Herbs Spices Med Plants 15(1):9-15. https://doi.org/10.1080/10496470902787444

Sadeghi H, Taban A (2021) Crushed maize seeds enhance soil biological activity and salt tolerance in caper (Capparis spinosa L.). Ind Crops Prod 160:113103. https://doi.org/10.1016/j.indcrop.2020.113103

Samari F, Baluchi L, Salehipoor H, Yousefinejad S (2019) Controllable phytosynthesis of cupric oxide nanoparticles by aqueous extract of Capparis spinosa (caper) leaves and application in iron sensing. Microchem J 150:104158. https://doi.org/10.1016/j.microc.2019.104158

Schraudolf H (1989) Indole glucosinolates of Capparis spinosa. Phytochemistry 28(1):259-260. https://doi.org/10.1016/0031-9422(89)85051-4

Shahrajabian MH, Sun W, Cheng Q (2020a) Exploring Artemisia annua L., artemisinin and its derivatives, from traditional Chinese wonder medicinal science. Not Bot Horti Agrobot Cluj Napoca 48(4):1719-1741. https://doi. org/10.15835/nbha48412002

Shahrajabian MH, Sun W, Soleymani A, Cheng Q (2020b) Traditional herbal medicines to overcome stress, anxiety, and improve mental health in outbreaks of human coronaviruses. Phytother Res 1:1-11. https://doi.org/ 10.1002/ptr.6888

Shahrajabian MH, Sun W, Cheng Q (2021a) Improving health benefits with considering traditional and modern benefits of Peganum harmala. Clin Phytosci 7(1):1-10. https://doi.org/10.1186/s40816-021-00255-7

Shahrajabian MH, Sun W, Cheng Q (2021 b) Asafoetida, a natural medicine for a future. Curr Nutr Food Sci 17:1-10. https://doi.org/10.2174/1573401317 666210222161609
Shahrajabian MH, Sun W, Khoshkharam M, Cheng Q (2021c) Caraway, Chinese chives and cassia as functional foods with considering nutrients and health benefits. Carpath J Food Sci Technol 13(1):101-119. https://doi. org/10.34302/crpjfst/2021.13.1.9

Shahrajabian MH, Sun W, Cheng Q (2021d) Molecular breeding and the impacts of some important genes families on agronomic traits: a review. Genet Resour Crop Ecol 68(3):1709-1730. https://doi.org/10.1007/ s10722-021-01148-x

Shahrajabian MH, Chaski C, Polyzos N, Tzortzakis N, Petropoulos SA (2021e) Sustainable agriculture systems in vegetable production using chitin and chitosan as plant biostimulants. Biomolecules 11(6):819. https://doi.org/ 10.3390/biom 11060819

Shahrajabian MH, Chaski C, Polyzos N, Petropoulos SA (2021f) Biostimulants application: a low input cropping management tool for sustainable farming of vegetables. Biomolecules 11(5):698. https://doi.org/10.3390/ biom11050698

Sharaf M, El-Ansari MA, Saleh NAM (2000) Quercetin triglycoside from Capparis spinosa. Fitoterapia 71(1):46-49. https://doi.org/10.1016/s0367-326x(99) 00116-1

Sher M, Alyemeni MN (2010) Ethnobotanical and pharmaceutical evaluation of Capparis spinosa L, validity of local folk and Unani system of medicine. J Med Plants Res 4(17):1751-1756

Stefanucci A, Zengin G, Locatelli M, Macedonio G, Wang C-W, Novellino E, Mahmoodally MF, Mollica A (2018) Impact of different geographical locations on varying profile of bioactives and associated functionalities of caper (Capparis spinosa L.). Food Chem Toxicol 118:181-189. https://doi. org/10.1016/j.fct.2018.05.003

Sun W, Shahrajabian MH, Cheng Q (2021a) Health benefits of wolfberry (Gou Qi Zi) on the basis of ancient Chinese herbalism and Western modern medicine. Avicenna J Phytomed 11(2):109-119

Sun W, Shahrajabian MH, Cheng Q (2021b) Fenugreek cultivation with emphasis on historical aspects and its uses in traditional medicine and modern pharmaceutical science. Mini Rev Med Chem 21(6):724-730. https://doi. org/10.2174/1389557520666201127104907

Taghavi MM, Nazari M, Rahmani R, Sayadi A, Hajizadeh MR, Mirzaei MR, Ziaaddini H, Hosseini-Zijoud SM, Mahmoodi M (2014) Outcome of Capparis spinosa fruit extracts treatment on liver, kidney, pancreas and stomach tissues in normal and diabetic rats. Med Chem 4(10):717-721. https://doi. org/10.4172/2161-0444.1000218

Tir M, Feriani A, Labidi A, Mufti A, Saadaoui E, Nasri N, Khaldi A, El Cafsi M, Tili N (2019) Protective effects of phytochemicals of Capparis spinosa seeds with cisplatin and $\mathrm{CCl}_{4}$ toxicity in mice. Food Biosci 28:42-48. https://doi. org/10.1016/j.fbio.2019.01.002

Tlili N, Elfalleh W, Saadoui E, Khaldi A, Triki S, Nasri N (2011) The caper (Capparis L): ethnopharmacology phytochemical and pharmacological properties. Fitoterapia 82(2):93-101. https://doi.org/10.1016/.fitote.2010.09.006

Tlili N, Mejri H, Anouer F, Saadaoui E, Khaldi A, Nasri N (2015) Phenolic profile and antioxidant activity of Capparis spinosa seeds harvested from different wild habitats. Ind Crops Prod 76:930-935. https://doi.org/10.1016/j. indcrop.2015.07.040

Tlili N, Feriani A, Saadoui E, Nasri N, Khaldi A (2017) Capparis spinosa leaves extract: Source of bioantioxidants with nephroprotective and hepatoprotective effects. Biomed Pharmacother 87:171-179. https://doi.org/10. 1016/j.biopha.2016.12.052

Twumasi MA, Tandoh A, Mante PK, Ekuadzi E, Boakye-Gyasi ME, Benneh CK, Kumadoh D, Woode E (2019) Leaves and stems of Capparis erythrocarpos, more sustainable than roots, show antiarthritic effects. J Ethnopharmacol 238:111890. https://doi.org/10.1016/j.jep.2019.111890

Vahid H, Rakhshandeh H, Ghorbani A (2017) Antidiabetic properties of Capparis spinosa L. and its components. Biomed Pharmacother 92:293-302. https://doi.org/10.1016/j.biopha.2017.05.082

Yahia Y, Benarbderrahim MA, Tlili N, Hannachi H, Ayadi L, Elfalleh W (2020) Comparison of three extraction protocols for the characterization of caper (Capparis spinosa L.) leaf extracts: evaluation of phenolic acids and flavonoids by liquid chromatography-electrospray ionization- tandem mass spectrometry (LC-ESI-MS) and the antioxidant activity. Anal Lett 53(9):1366-1377. https://doi.org/10.1080/00032719.2019.1706546

Yang T, Wang C-H, Chou G-X, Wu T, Cheng X-M, Wang Z-T (2010) New alkaloids from Capparis spinosa: structure and X-ray crystallographic analysis. Food Chem 123(3):705-710. https://doi.org/10.1016/j.foodchem.2010.05.039 
Yue-lan C, Xin L, Min Z (2010) Capparis spinosa protects against oxidative stress in systemic sclerosis dermal fibroblasts. Arch Dermatol Res 302:349-355. https://doi.org/10.1007/s00403-009-0998-7

Zarei M, Seyedi N, Maghsoudi S, Shahbi Nejad M, Sheibani H (2021) Green synthesis of $\mathrm{Ag}$ nanoparticles on the modified graphene oxide using Capparis spinosa fruit extract for catalytic reduction of organic dyes. Inorg Chem Commun 123:108327. https://doi.org/10.1016/j.inoche.2020. 108327

\section{Publisher's Note}

Springer Nature remains neutral with regard to jurisdictional claims in published maps and institutional affiliations.

\section{Submit your manuscript to a SpringerOpen ${ }^{\circ}$ journal and benefit from:}

- Convenient online submission

- Rigorous peer review

- Open access: articles freely available online

- High visibility within the field

- Retaining the copyright to your article

Submit your next manuscript at $\boldsymbol{\nabla}$ springeropen.com 